\title{
Physiological differences between wild and cultured bivalves in Prince Edward Island, Canada
}

\author{
Valentin Montagnac ${ }^{1}$, Thomas Guyondet ${ }^{2}$, Luc Comeau ${ }^{2}$ and Réjean Tremblay ${ }^{1, *}$ \\ ${ }^{1}$ Institut des Sciences de la Mer, Université du Québec à Rimouski, 310 allée des Ursulines, C.P. 3300, Rimouski, \\ QC G5L 3A1, Canada \\ ${ }^{2}$ Fisheries and Oceans Canada, Gulf Fisheries Centre, Science Branch, P.O. Box 5030, Moncton, NB E1C 9B6, Canada
}

Received 18 September 2019 / Accepted 31 May 2020

Handling Editor: Pierre Boudry

\begin{abstract}
Bivalve culture in Canada increased by 25\% from 2000 to 2016. In Prince Edward Island (PEI), bivalves are cultivated in bays and estuaries and there is limited space for further aquaculture expansion. Thus, there is merit in developing a numerical model determining the abundance of bivalve populations in relation to their food availability in order to assess the carrying capacity of shellfish growing areas. This modelling will take into account the different bivalve species present in the bay, as the cultivated Mytilus edulis and Crassostrea virginica and wild, M. edulis, C. virginica, Mya arenaria and Mercenaria mercenaria. As a first step toward a modelling goal, this study compared the physiological differences of the 6 bivalve groups. Three physiological parameters were measured: clearance rate, oxygen consumption and assimilation to determine the energy budget or scope for growth (SFG). These measurements were carried out on individuals contained in metabolic chamber at summer and autumn temperatures $\left(20\right.$ and $8{ }^{\circ} \mathrm{C}$, respectively). Our results show that $M$. edulis is best adapted to these temperature in PEI as it maintains high SFG at both temperatures. For $C$. virginica and $M$. arenaria, high physiological parameters under summer conditions were observed, followed by a decrease in autumn. For M. mercenaria rates were low at both temperatures indicating a persistently low growth potential. These results demonstrate the adaptive physiological capacity of each species and provide insight into the underlying reasons some species such as $C$. virginica and $M$. mercenaria are at their northern distribution limit in the Gulf of St. Lawrence. Finally, no differences in the SFG between cultivated and wild bivalves have been observed. These results are discussed within the context of estimating the impact of each bivalve group in bays environment from PEI and particularly on food availability.
\end{abstract}

Keywords: Bivalves / ecophysiology / carrying capacity / Malpeque Bay

\section{Introduction}

The development of bivalve aquaculture has been principally established in protected near-shore areas such as bays and estuaries (Perez Camacho et al., 1991; Drapeau et al., 2006; Myrand et al., 2009). The production capacity of a cultured area is dependent upon several abiotic and biotic factors and particularly the renewal rate of food particles (Cranford et al., 2003). The ability of bivalves to filter organic particles from large water volumes may lead to an overall reduction in food availability in bays used for intensive aquaculture (Guyondet et al., 2015a). Thus, the determination of the biomass is important in bivalve aquaculture, and more

*Corresponding author: rejean_tremblay@uqar.qc.ca recent management practices have implemented numerical models to estimate the carrying capacity of cultivated areas (Filgueira et al., 2015a, 2015b). Carrying capacity modelling is one of the most useful concepts to assess the development of shellfish culture and has been the subject of several investigations. Since the precursor work of Incze et al. (1981), several aspects have been integrated in carrying capacity models, such as considerations for physical aspects (hydrodynamics), species (physiology and genetics), husbandry practices (biomass), the environment and economic issues (Byron and Costa-Pierce, 2013; Filgueira et al., 2015a; Gibbs, 2007; Guyondet et al., 2015b; 2015a; 2010; McKindsey et al., 2006).

Along the northwestern Atlantic coastline, mussel aquaculture production is largely concentrated in Prince Edward Island (PEI), where some of the most important cultivated sites 


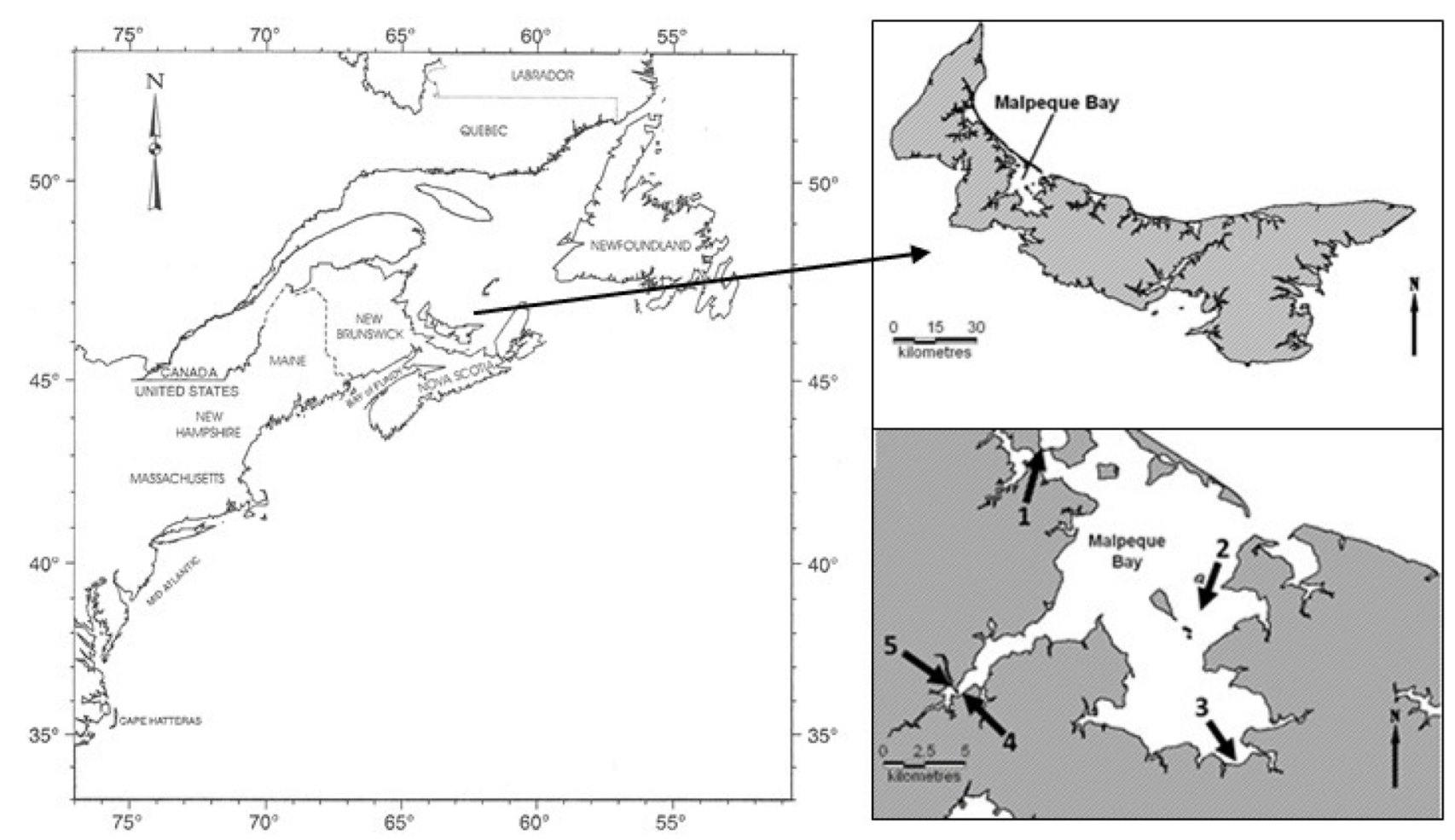

Fig. 1. Location of the sampling site in Malpeque Bay, Prince Edward Island in the east coast of North America. Sampling of cultivated oysters Crassostrea virginica at site 1 (N46.61131 W63.87932), cultivated mussels Mytilus edulis at site 2 (N46.31232 W63.45451), quahogs Mercenaria mercenaria and softshell clams Mya arenaria at site 3 (N46.44303 W63.71028), wild mussels M. edulis at site 4 (N46.47392 W63.94366), and wild oysters $C$. virginica at site 5 (N46.47901 W63.95007).

are near the productive carrying capacity (Comeau et al., 2008a; Cranford et al., 2008; Grant et al., 2007; Guyondet et al., 2015a). The province of PEI produces approximately $80 \%$ of the blue mussels in Canada (Statistique Canada, 2015). A moratorium adopted in 1999 limits the development of new aquaculture activity in PEI. However, Malpeque Bay in PEI is presently a targeted area for increasing mussel farming coverage to meet the current market demands. Malpeque Bay is a large (19 $640 \mathrm{ha}$ ) and shallow embayment open to the Gulf of St. Lawrence through multiple connections and composed of several basins with a river system discharging into different points (Fig. 1; DFO, 2015). A carrying capacity model has been developed (Filgueira et al., 2015b) to validate a potential expansion scenario where 590 ha of mussel farming area would be added to the system. The model, which was based upon the best scientific assessments available at the time, predicted $8 \%$ decrease in mussel growth rate and $17.7 \%$ in Chlorophyll-a concentration. However, the sensitivity tests identified key processes that warrant further attention, such as the role of wild bivalves relative to cultivated ones. Integrating these filter feeders into the model may substantially improve the predictive accuracy and strengthen the advice to stakeholders.

In Malpeque Bay, there are several native species of bivalves with different lifestyles. Some are burrowing species (soft-shell clams Mya arenaria and quahogs Mercenaria mercenaria) while others are non-burrowing (blue mussels Mytilus edulis and American oysters Crassostrea virginica). Their respective contribution to carrying capacity estimates for aquaculture is unknown. The main cultivated species, mussels and oysters, are mainly maintained in suspension in the water column. Mussels are produced on sleeves suspended on longlines (Mallet and Myrand, 1995) and since the early 1990s, the traditional oyster culture of relaying seed to bottom culture is being progressively replaced by suspended culture with the use of floating cage (Comeau, 2013). For both species, the local seed is generally obtained by using artificial collectors. For $C$. virginica a recent study in PEI using stable isotopes and fatty acid biomarkers to identify trophic sources of oysters diets indicated that pelagic phytoplankton represented the main food source of both suspended (cultivated) and bottom (wild) stocks (Sonier et al., 2018). Surprisingly, bottom oysters did not show significant preference for detrital or bacterial organic matter. However, Comeau (2013) reported that gill area per unit of dry tissue is lower for suspended cultured oysters, suggesting differences in clearance rate allometry between wild and cultivated oysters. In this study, we expand the comparison between suspended "cultivated" and wild oysters and mussels by assessing several physiological rates under summer and autumnal thermal conditions, and also by including other bivalve species present in Malpeque Bay. As seasons have a major impact on the physiological rate (Riisgård and Seerup, 2003; Widdows, 1978; Winter, 1978), a summer and autumn comparison, under standardized food conditions, between species has been included and mostly related to interactive effect of temperature and reproductive status. Our end objective was to measure the bivalve category energetic budget and the potential contribution of each bivalve 


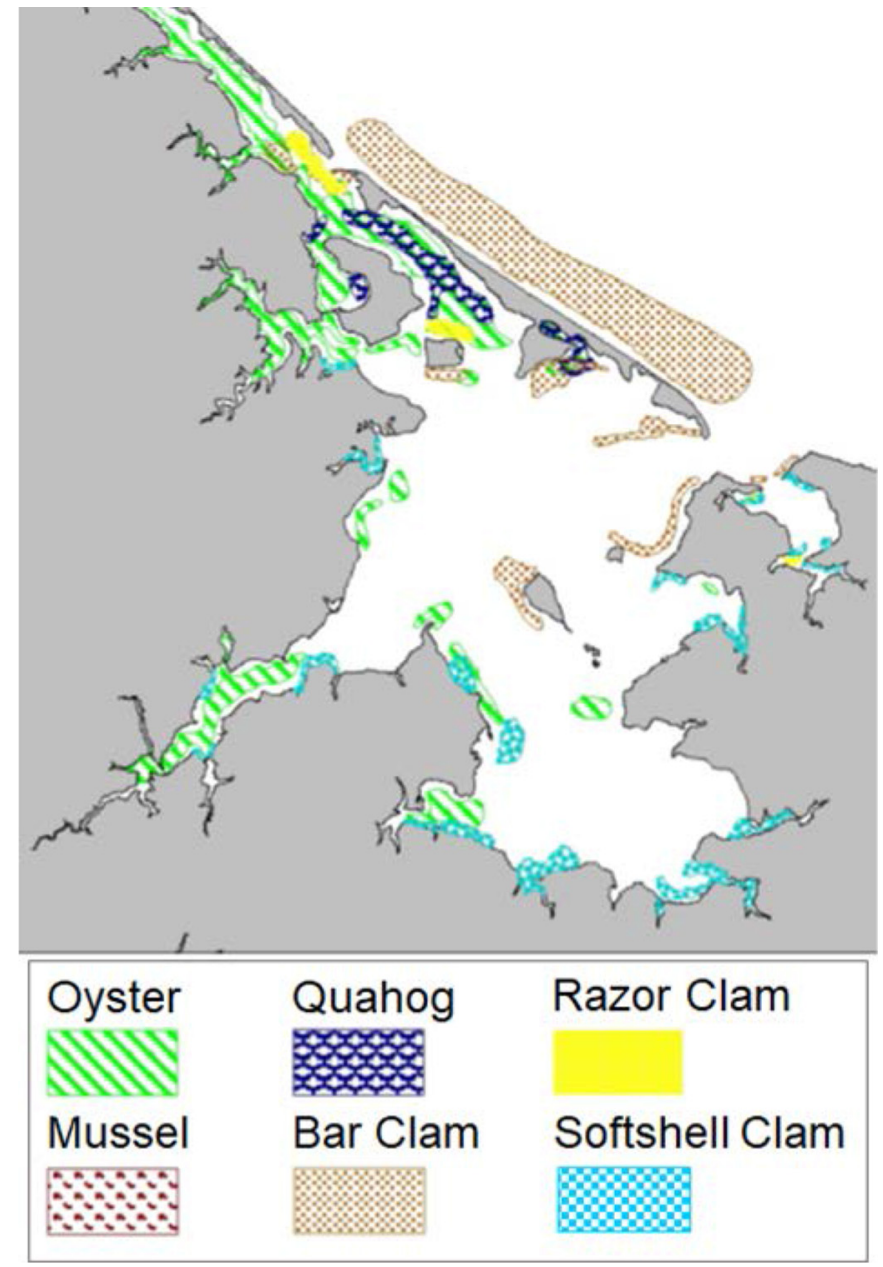

Fig. 2. Mollusc fishing locations in the Malpeque Bay area, based on interviews conducted with local fishermen in 1996 and 1997 (Source: DFO unpublished data. Wild mussels are present in the bay but not fished. The Southern Gulf of St. Lawrence Coastal Fishery Resources Mapping Project).

category on the food resources. We hypothesized that different bivalve species with different life history (wild or aquaculture) may not have the same seasonal impact on food resources in the bay studied has been tested.

\section{Material and methods}

\subsection{Bivalves sampling and maintenance}

The study included four wild species naturally-inhabiting the seabed of Malpeque Bay: the American oyster $C$. virginica, blue mussel $M$. edulis, quahog $M$. mercenaria and softshell clam $M$. arenaria. In addition, mussels and oysters from suspended culture farms were also sampled, thereby increasing to 6 the number of experimental bivalve groups. All bivalves were collected in Malpeque Bay on May 23, 2016 and August 8,2016 when sea water temperatures were 11 and $21^{\circ} \mathrm{C}$, respectively (Fig. 1). Wild individuals were randomly collected within populations (Fig. 2). Cultivated individuals were sampled from five oyster culture cages and mussel polyethylene sleeves. About 100 individuals of variable sizes from each group were collected and transported on ice according to DFO regulations (transfer permit Q1\&T16-05) to the UQAR-ISMER wet laboratory in Pointe-au-Père (Qc, Canada). Individuals were all maintained in 12 thermoregulated aquariums of 301 each having its own biofiltration process, aeration, and temperature control unit (6-Pack Arctic model, Aquabiotech, Coaticook, Qc, Canada). Temperature was monitored continuously and each group was maintained in 2 replicate aquariums. Infaunal species were individually placed halfway buried in $250 \mathrm{ml}$ filtered and autoclaved sand. The water temperature in each aquarium was gradually adjusted $\left(1^{\circ} \mathrm{C} \mathrm{d}^{-1}\right)$ (Widdows, 1985$)$ in order to reach the desired experimental temperature, respectively $20^{\circ} \mathrm{C}$ and $8{ }^{\circ} \mathrm{C}$. These temperatures represent sea water conditions observed in bays from this area in these seasons (Waite et al., 2005). Bivalves were fed twice per day with a mixed suspension of live microalgae Tisochrysis lutea (CCMP 1324), Chaetoceros neogracilis (CCMP 1317), Pavlova lutheri (CCMP 459) and Nannochloropsis occulata (CCMP 525) at a rate of 60000 cells ind ${ }^{-1} \mathrm{~d}^{-1}$. Microalgae strains were obtained from the Center for Culture of Marine Phytoplankton (CCMP) Bigelow Laboratory for Ocean Sciences (West Boothbay Harbor, ME, USA). The salinity was maintained at $27 \pm 2$, the value observed during each field sampling. Following the temperature adjustment of the aquariums, a four-week laboratory acclimation period was applied prior to physiological measurements.

\subsection{Clearance rate}

Clearance rate $(\mathrm{CR})$ represents the volume of water completely cleared of particles per unit of time (Bayne, 1976). For each season studied, twenty animals of each group were used to estimate $\mathrm{CR}$ for a total of 240 animals (20 individuals $\times 6$ groups $\times 2$ seasons). Physiological measurements were realized simultaneously on 10 individuals and a blank (empty shell for oysters and mussels and empty shell buried in autoclaved sand containers for quahogs and soft-shell clams) each day using the static method (Pernet et al., 2007, Gilek et al., 1992, Widdows and Johnson, 1988). Individuals were held in a physiological chamber of $763 \mathrm{ml}$ for oysters and mussels and $1357 \mathrm{ml}$ for quahogs and soft-shell clams filled with $0.2 \mu \mathrm{m}$ filtered and UV treated seawater saturated in oxygen. Each individual was acclimated to the chamber for $1 \mathrm{~h}$ at the same temperature as the holding aquariums $\left(20^{\circ} \mathrm{C}\right.$ or $8^{\circ} \mathrm{C}$ ). For burrowing species, the individual container with filtered autoclaved sand was changed before physiological measurements. After acclimation, T. lutea was added in the chamber at an initial concentration of 30000 cells ml $^{-1}$ and particle concentration measured every 20 minutes for 1 hour using a Beckman Z2 Coulter Counter fitted with a $70 \mu \mathrm{m}$ aperture tube (Beckman, Mississauga, On, Canada). The coulter was set to measure particles ranging between 4 and $8 \mu \mathrm{m}$. CR values reported here correspond to those obtained during the 20-minute interval that exhibited the greatest depletion of particles (Cusson et al., 2005; Gilek et al., 1992). This approach avoided the potential underestimation of CR due to particle levels falling below a critical threshold for the valve opening (Newell et al., 2001; Riisgård and Seerup, 2003). 
CR was calculated according to the formula:

$$
C R=((\ln C 1-\ln C 2)-S) * V * T^{-1},
$$

where $C 1$ and $C 2$ are the particle concentrations at the beginning and end of the 20-minute interval showing the highest depletion rate, subtract the blank; $S$ is an exponential sedimentation but was null here because water was stirred during the experiment; $V$ is the chamber volume of water $(763 \mathrm{ml}$ or $1357 \mathrm{ml})$; and $T$ is the time $(20 \mathrm{~min})$ elapsed between measurements. No mortality occurred during the course of the experiment. However, some individuals released gametes and were excluded from data analyses due to increasing particle counts.

\subsection{Oxygen consumption and assimilation for scope for growth (SFG) estimation}

In order to estimate the scope for growth (SFG), oxygen consumption and food assimilation rates were measured. As excretion represents $<5 \%$ of the energy budget in most bivalves, it was ignored (Bayne, 1999; Pernet et al., 2008). Following CR determination, each individual animal was transferred into a hermetically closed metabolic chamber setting described in Tremblay and Landry (2016), allowed to acclimate for $1 \mathrm{~h}$, and thereafter subjected to oxygen consumption measurement during $1 \mathrm{~h}$ using a polarographic electrode (YSI 5331) and a micro-oxymeter (YSI 5300A Biological Oxygen Monitor, Yellow Springs, OH, USA). To validate absence of bacterial respiration associated with shell or sand, a blank control composed of an empty shell was used for each series of measurement. Partial oxygen pressure in physiological chambers was kept well-mixed using a magnetic stirrer and output oxygen signal was monitored continuously on a flatbed chart recorder (Cole-Parmer, Qc, Canada) until there was a $20 \%$ decrease.

Individuals were transferred from the metabolic chambers to holding aquariums $\left(20^{\circ} \mathrm{C}\right.$ or $\left.8^{\circ} \mathrm{C}\right)$ and fed during $12-24 \mathrm{~h}$. Faeces were then collected to estimate assimilation rate, defined as the product of ingested energy and absorption efficiency (Widdows and Johnson, 1988) and measured using the Conover ratio (Conover, 1966). Faeces were filtered in triplicate using pre-combusted $\left(2 \mathrm{~h}\right.$ at $\left.450^{\circ} \mathrm{C}\right)$ and preweighed $25 \mathrm{~mm}$ GFC filters and rinsed with isotonic ammonium formate $(3.2 \%)$. Filters were dried at $70^{\circ} \mathrm{C}$ for $48 \mathrm{~h}$, cooled to room temperature in a desiccator, and reweighed (dried weight). Secondly, filtered samples were then combusted $6 \mathrm{~h}$ at $450{ }^{\circ} \mathrm{C}$, cooled in a desiccator, and finally weighed again (burned weight). The mixed suspension of live mircroalgae used for feeding was filtered in triplicate and the same process for filter analysis was applied. This procedure provided estimates of the organic and inorganic fractions contained in the faeces and the food source, which were applied to equation:

$$
A b=(F-E) /((1-E) * F),
$$

where $A b$ is absorption efficiency; $F$ is the ash-free dry mass/dry mass ratio of the food; $E$ is ash-free dry mass/dry mass ratio of the faeces. At the end of these physiological measurements, biometric measurements (shell length, dried tissue and dried shell mass after desiccation at $70^{\circ} \mathrm{C}$ for $72 \mathrm{~h}$ ) were taken for each individual.

The relationships between the clearance rate and oxygen consumption with dry tissue mass were determined to establish the allometric correction factor to standardize each physiological measurement for an individual of $1 \mathrm{~g}$. Data were $\log$ transformed prior to analyses for the equation. The allometric correction was applied to our measurements as follows:

$$
P s=(M s / M e)^{b} * P e
$$

where $P s$ is the physiological measure (oxygen uptake or clearance rate) of a standard individual of $1 \mathrm{~g}$ of dry Tissue Mass (DTM), $P e$ is the physiological measurement of experimental individuals, $M s$ is the standard mass $(1 \mathrm{~g}), \mathrm{Me}$ is the DTM of the experimental individual and $b$ is the exponent of the equation scaling physiological measurement to dry mass. This allometric correction was applied to SFG calculation, as described by Widdows and Johnson (1988). The SFG is measured by subtracting the energy respired and excreted (considered negligible) from the energy absorbed from the food as follows:

$$
\begin{gathered}
P=A-R \\
P=(C * A b)-(V o 2 * 20.33) \\
P=(C R * P O M * 23) * A b-((V o 2 * 20.33))
\end{gathered}
$$

where $P=$ energy incorporated into somatic growth and gamete production; $A=$ energy absorbed from the food $=C^{*}$ $A \mathrm{~b} ; C=$ clearance rate $(C R)\left(1 \mathrm{~h}^{-1} \mathrm{~g}^{-1}\right)^{*} P O M\left(\mathrm{mg} \mathrm{l}^{-1}\right)^{*}$ $23 \mathrm{~J} \mathrm{mg}^{-1}$ ash-free DTM; $P O M=$ particular organic matter concentration; $A \mathrm{~b}=$ absorption efficiency; $R=$ energy catabolized $=\mathrm{V}_{\mathrm{O} 2}\left(\mathrm{ml} \mathrm{O}_{2} \mathrm{~h}^{-1} \mathrm{~g}^{-1}\right)^{*} 20.33 \mathrm{~J} \mathrm{ml}^{-1} \mathrm{O}_{2}$ (Widdows et al., 1985).

\subsection{Statistical analyses}

To determine at each season, summer and autumn, the effect of bivalve groups on physiological characteristics, oneway ANOVA was performed using the bivalve group as a factor (6 levels) and the filtration rate, oxygen consumption, assimilation and the SFG as dependent variables. A LSmean test was used to compare the different groups. For SFG, only the individuals who had complete datasets were kept for performing the statistical analyses. A two-way ANOVA was performed in order to demonstrate the absence of bivalve groups (6 levels) and season effects (2 levels) on the mean size of the selected sample (number of individuals). Normality was approved by a Shapiro-wilk test $(P<0.05)$ and the homogeneity of the variance-covariance matrices were graphically assessed on residue data. Data were $\log +1$ transformed in order to achieve normality of residuals and homogeneity of variances. Statistical analyses and graph production were achieved using R.Studio and SigmaPlot 12.5 . 
Table 1. Two-way Anova testing the potential shell length difference between each bivalve group and season with mean, standard deviation (SD) minimum and maximal values for each species with season pooled.

\begin{tabular}{llllll}
\hline Source & Type III SS & df & Mean Squares & $F$-ratio & $P$-value \\
\hline Temperature & 611.498 & 1 & 611.498 & 2.707 & 0.102 \\
Group & 2419.785 & 5 & 5 & 483.957 & 0.064 \\
Temperature* Group & 1189.418 & 136 & 237.884 & 0.383 \\
Error & 30718.0 & SD & Minimum & Maximum \\
Length (mm) & Mean & 20.8 & 24.2 & 78.5 \\
Wild oysters & 55.9 & 14.4 & 21.1 & 77.3 \\
Cultivated oysters & 48.9 & 16.3 & 23.3 & 77.4 \\
Wild mussels & 49.9 & 10.8 & 20.3 & 65.1 \\
Cultivated mussels & 40.8 & 11.9 & 19.5 & 63.2 \\
Wild softshell clams & 45.8 & 16.6 & 18.12 & 74.9 \\
Wild quahogs & 48.8 & &
\end{tabular}

Table 2. Allometric exponents used to standardize physiological measurements for each species. Ps $=(\mathrm{Ms} / \mathrm{Me})^{\mathrm{b} *} \mathrm{Pe}$.

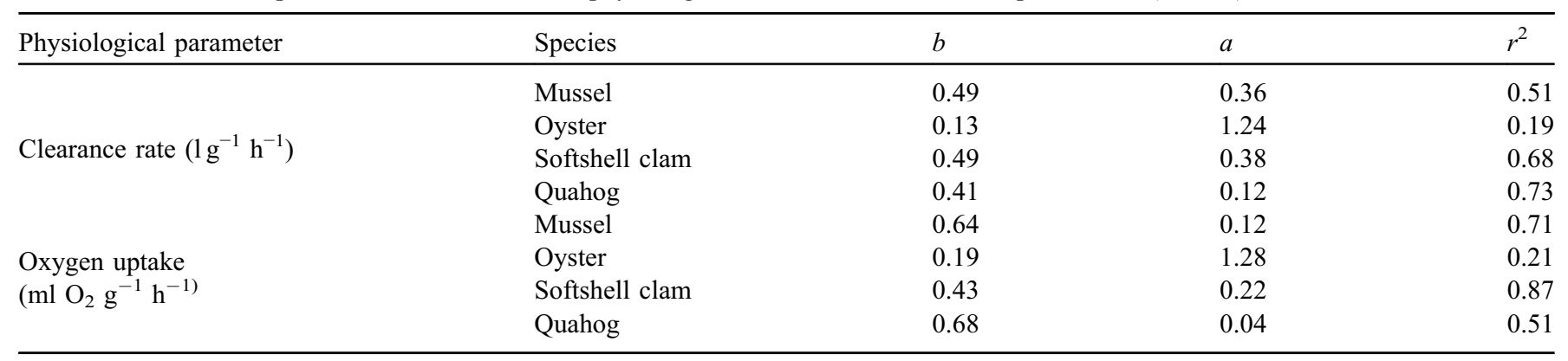

\section{Results}

Shell lengths of individuals were similar between bivalve groups and the two seasons (Tab. 1). Most individuals $(n=168)$ had a complete dataset for SFG estimation. Allometric relationships (Tab. 2) were estimated from physiological rates measured on summer $\left(20^{\circ} \mathrm{C}\right)$ and autumn $\left(8^{\circ} \mathrm{C}\right)$ conditions and for individuals ranging from 18 to $83 \mathrm{~mm}$ in shell length. Those sizes corresponded with minimal size for the estimation of physiological measurements in the experimental set-up and maximum size of individual sampled. As similar allometric relationships were obtained for wild and suspended bivalves, data were pooled by species. The allometric exponent (b-values) varied between species from 0.41 to 0.49 for clearance rates and from 0.43 to 0.78 for oxygen consumption except for oysters showing for both physiological measurement values less than 0.2 (Tab. 2). These allometric relationships were applied to standardize the clearance rate and oxygen consumption.

At the microalgae concentration used in physiological chambers, no pseudofaeces production was observed. CR were different among bivalve groups both under summer and autumn conditions (Fig. $3 \mathrm{~A}, \mathrm{~B}$ : $\mathrm{df}=5, F=2.84, P=0.02$; $\mathrm{df}=5, F=41.61, P<0.0001$, respectively). Similar observations were recorded in summer and autumn for oxygen consumption (Fig. 3C, D: $\mathrm{df}=4, F=3.38, P<0.02$; df=5, $F=2.411, \quad P=0.48$, respectively), for food assimilation
(Fig. 3E, F: $\mathrm{df}=5, F=19.59, P<0.0001$; $\mathrm{df}=5, F=29.47$, $P<0.0001$, respectively) and for estimation of scope for growth (Fig.4: df=5, $F=10.94, P<0.0002$; df=5, $F=33$, $P<0.0001$, respectively). Generally, the summer temperature $\left(20^{\circ} \mathrm{C}\right)$ was associated with elevated $\mathrm{CRs}$, oxygen consumption and SFG; however, differences between bivalve groups varied according to the temperature.

In summer temperature, variable CR values were observed for cultivated and wild oysters, whereas $\mathrm{CR}$ values remained relatively high throughout the study for all other bivalves groups with the exception of $M$. mercenaria (CRs approximately four times lower than other groups, Fig. 3A). In regards to the autumn temperature $\left(8^{\circ} \mathrm{C}\right)$, quahogs maintained their low CR values while $C$. virginica and $M$. arenaria reduced their CR. However, mussels $M$. edulis (wild and cultivated) exhibited CR values 2-3 times higher than other groups (Fig. 3B). In summer temperature, the oxygen consumption was similar for bivalves except farmed mussels that had significantly lower than other species (Fig. 3C). In autumn temperature, values were generally lower, and cultivated mussels and softshell clam $M$. arenaria were significantly different (Fig. 3D). Unfortunately, due to technical difficulties, measurement of oxygen consumption for soft-shell clams in summer were lost. Thus, it was not possible to evaluate SFG for this species in summer. For assimilation efficiency, values up to $95 \%$ were observed (Fig. 3E, F). SFG patterns had similar trends than CRs. We observed variable SFG values in summer 

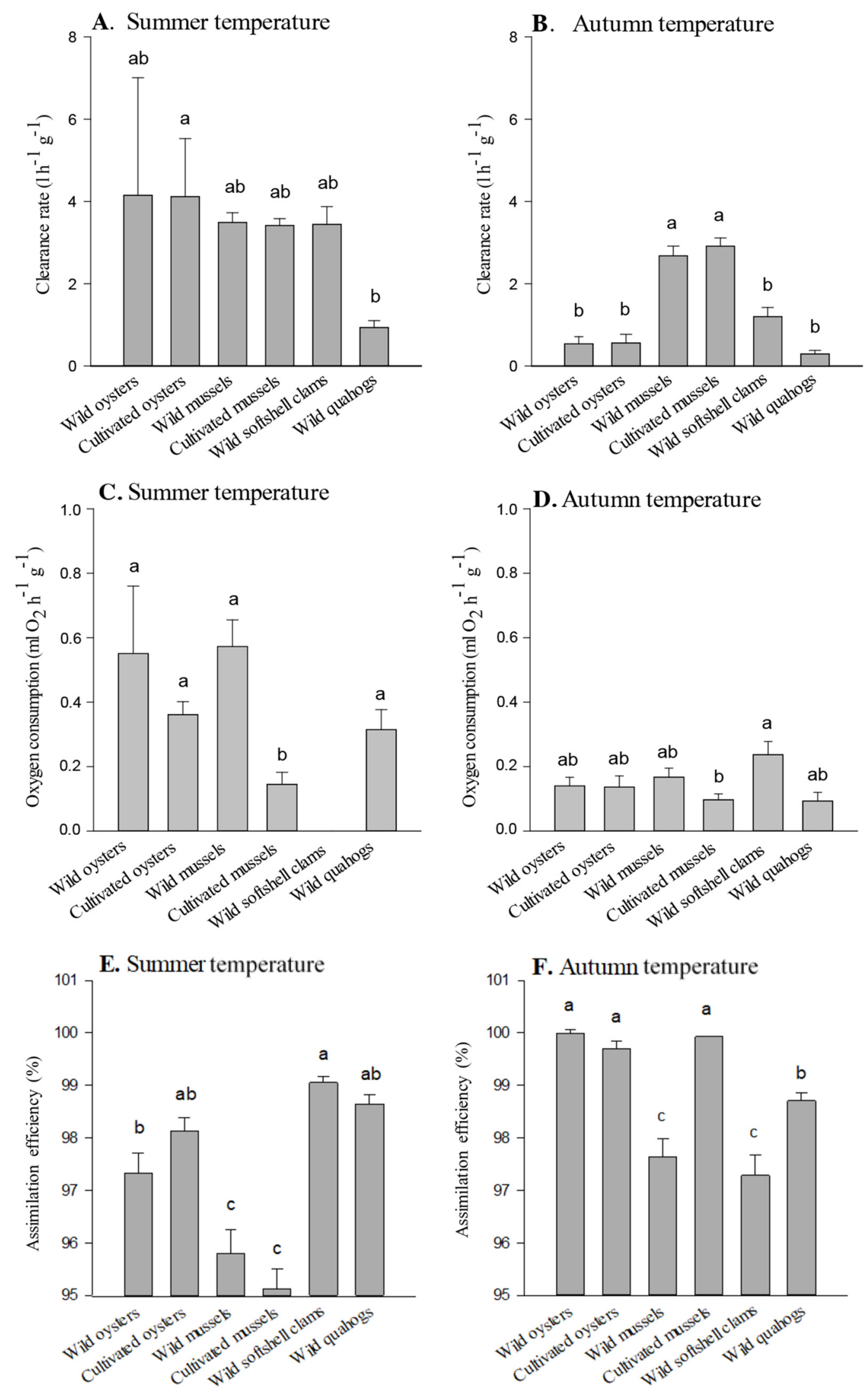

Fig. 3. Physiological measurements of different bivalves groups. Clearance rates between (A) summer and (B) autumn, oxygen consumption levels in (C) summer and (D) autumn and assimilation rates according to (E) summer and (F) autumn. Mean \pm standard error (SE) and $\mathrm{n}$ between 7 and 20 per group. Letters correspond to significant differences $(\mathrm{p}<0.05)$ obtained by one-way ANOVA and LSmean tests. 

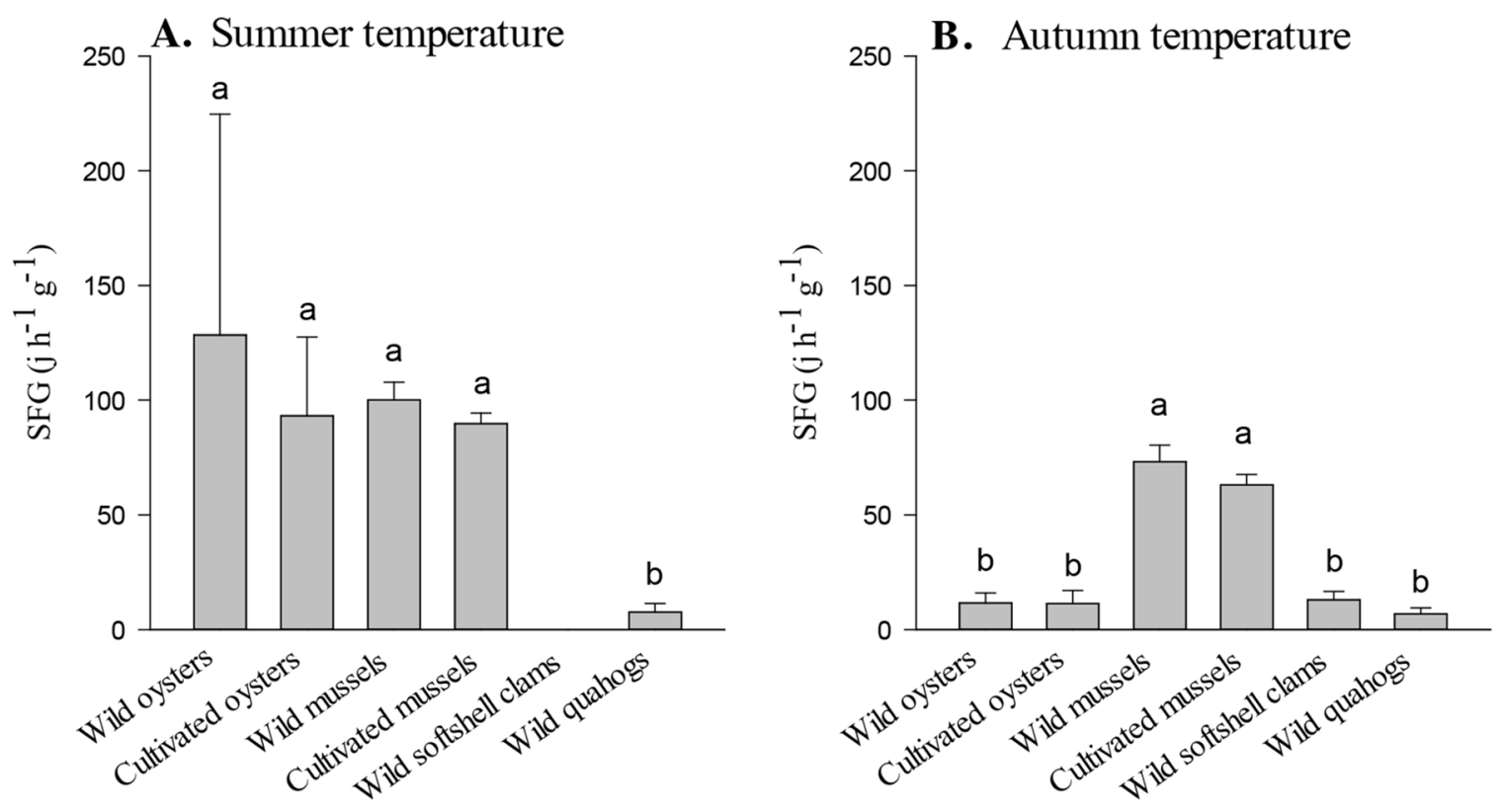

Fig. 4. Scope For Growth (SFG; $\mathrm{J} \mathrm{h}^{-1} \mathrm{~g}^{-1}$ ) between (A) summer and (B) autumn for each bivalves group. Mean \pm standard error (SE) and $\mathrm{n}$ between 6 and 19 per group. Letters correspond to significant difference $(\mathrm{p}<0.05)$ obtained by one-way ANOVA and LSmean tests.

for oysters and relatively high values for all other bivalves groups (Fig. 4) with the exception of quahogs, which were characterized by a SFG approximately 7-18 times lower than other groups (Fig. 4). In autumn temperature quahogs maintained their low SFG values and other groups lowered their SFG, except for mussels (wild and cultivated), which exhibited CR values 5-12 times higher than other groups.

\section{Discussion}

\subsection{Differences between species and seasons}

Results demonstrate interspecific and seasonal differences in the physiological response of bivalves and allow to assess their impact on food resources. The allometric exponent (bvalues) measured are generally in accordance with literature for mussels, clams and quahogs (Riissgard, 1988, Tremblay et al., 1998). However, Comeau, (2013) observed higher values for $\mathrm{CR}$ b-factor in bottom $(0.78)$ and suspended oysters (0.41).

Water temperature is one of the main environmental factors regulating bivalve physiology and for temperatures ranging from 8 to $20^{\circ} \mathrm{C}$, the physiological activity have been demonstrated to be extremely variable from one species to another (Comeau et al., 2008b; Jørgensen et al., 1990; Riisgård and Seerup, 2003; Walne, 1972). Several other factors also impact bivalve physiology, such as the reproductive cycle (Bayne, 2000; Cranford and Hill, 1999; Tedengren et al., 1990), size (Le et al., 2017) and food particle characteristics (types, size, nutritional quality and abundances; Denis et al., 1999; Sonier et al., 2016). To limit the impact of these factors, individuals were sampled from different sizes and feeding regime was standardized during laboratory acclimation and measurements. However, the reproductive cycle could have an impact in the results, as summer is the reproductive period for all these bivalves. The health status of bivalves could also impact physiological conditions. However, presence of pathogens and parasites, like Ancistrum mytili, mussel protozoan $\mathrm{X}$ or rickettsial infection have been reported but at very low prevalence and intensities in bivalves from the Gulf of St. Lawrence (Tremblay et al., 2012). Exception for hemic neoplasia in $M$. arenaria, where prevalence and intensities are largely higher, but restricted to another area of PEI (Delaporte et al., 2008).

Quahogs, M. mercenaria seem poorly adapted to PEI environmental conditions, which is the northern limit of their geographical distribution (Harte, 2001). For both temperatures studied $\left(8\right.$ and $20^{\circ} \mathrm{C}$ ), CR and SFG values were very low. The indicator of energy invested in growth and reproduction (SFG) was 8 times lower than the other bivalve species studied. CR values are comparable with Bricelj et al. (2001) and Harke et al. (2011), respectively $0.41 \mathrm{~h}^{-1} \mathrm{~g}^{-1}$ and 0.3 to $0.81 \mathrm{~h}^{-1} \mathrm{~g}^{-1}$. Quahogs growth ceases below $9{ }^{\circ} \mathrm{C}$ and above $31^{\circ} \mathrm{C}$ (Jones et al., 1989) and most rapid growth is reported over $20^{\circ} \mathrm{C}$ (Ansell, 1968). As a result wild quahogs reach commercial size (25.4 $\mathrm{mm}$ ) between 6 and 8 years in PEI (Ansell, 1968; Landry et al., 1993) in comparison with 2-3 years in Florida (USA) (Arnold et al., 1991; Jones et al., 1990). SFG result may explain why at its northern limit of distribution, $M$. mercenaria is frequently subject to extinction and natural or transplantation recolonization episodes occur (Dillon and Manzi, 1992; Hilbish, 2001). The low clearance rates of quahogs in summer and autumn temperatures, combined with the low distribution observed in the Malpeque Bay area, suggest that this species has a negligible impact on suspended food availability. Recent work showed that interactions between lectins found in the mucus covering bivalves feeding organs, the gill architecture and carbohydrates found on the microalga cell surface could play a central role in the selection process of bivalves' food (Jones et al., 2020). However, to the best of our knowledge no 
information is available on the role of carbohydrate-lectin interactions in particle selection of $T$. lutea used for $\mathrm{CR}$ measurement between the different bivalve species studied. Based on the particle's size, the use of T. lutea having a size between 4 and $8 \mu \mathrm{m}$ could not be totally optimal to estimate clearance rates. Is it generally recognized that $100 \%$ retention efficiency is observed for particles larger than $6 \mu \mathrm{m}$ and all bivalve species used in this study showed retention efficiency below 90\% for particle size between 1 and $4 \mu \mathrm{m}$ (Rosa et al., 2018).

The Gulf of St. Lawrence is also the northern distribution limit where C. virginica oysters (Carriker and Gaffney, 1996) can be observed. Oysters CR and SFG values in summer showed the highest values compared to other species studied (Figs. 3 and 4). However, values decreased markedly at $8{ }^{\circ} \mathrm{C}$, suggesting an adaptation to cold waters allowing energy maintaining in the winter months, as was already demonstrated in the literature (Loosanoff, 1958; Comeau et al., 2012; 2008b; Filgueira et al., 2013). At $9{ }^{\circ} \mathrm{C}$, only $50 \%$ of individuals showed filtration activity (Comeau et al., 2008b), and at $5^{\circ} \mathrm{C}$ some of them can feed and produce feces but in negligible proportions (Comeau et al., 2012). CR results for oysters are comparable to other studies (Comeau, 2013; Pernet et al., 2008; Riisgård, 1998) and confirm the marked seasonality in physiological activity for this particular species. Thus in summer, they may impact significantly suspended food levels in the bay, particularly since oysters are widely distributed in the system. However, their impact could rapidly decrease when temperature drops in autumn and winter.

According to Riisgård and Seerup (2003) softshell clams display a different behavior to adapt to very cold waters. They noticed that contrary to the general assumption that change in poikilotherm's physiological rates is exponential, $M$. arenaria showed a linear increase in CR between 4 and $22^{\circ} \mathrm{C}$ with a weak ability of temperature acclimation. Nonetheless, they are present along the northeastern American coast up to the Labrador shores (Abbot, 1974). Based on CR and SFG results at $8^{\circ} \mathrm{C}, M$. arenaria and $C$. virginica are equally poorly adapted to cold waters when compared to M. edulis. Thus, as they are widely distributed but their biomass is unclear in Malpeque Bay, their impact on the food resources seems similar to oysters, with an important impact in summer and a low impact in autumn and winter. Softshell clams have a CR equivalent to mussels only in summer.

Finally, results indicate that the mussel $M$. edulis seem the best adapted bivalve to the range of temperatures tested. For this species, CR was high both in summer and autumn, thus allowing enhanced SFG values to persist at low temperatures. These results are in agreement with earlier observations showing that all mussels in a population maintained filtration activity at $9{ }^{\circ} \mathrm{C}$ (Comeau et al., 2008b). Furthermore, for this species, some degree of physiological activity has even been recorded under ice covered $\left(<0{ }^{\circ} \mathrm{C}\right.$ ) winter conditions (Cusson et al., 2005; Comeau et al., 2008b). Thus, our results pertaining to $M$. edulis temperature tolerance in maintaining a high physiology activity at low temperature, are consistent with several studies (Comeau et al., 2015; 2008b, Tremblay et al., 2011; 1998; Trottet et al., 2008). Mussels are well adapted to cold waters, explaining their distribution and abundance from North Carolina (USA) to Baffin Island (Canadian Arctic) (Gosling, 1992). It is concluded that they probably have an important impact on the suspended food resources of Malpeque Bay, particularly in autumn and spring. However, this impact would be attributable mainly to cultivate mussels, as wild mussels have been observed only in very limited areas of the Malpeque system.

Physiological characteristics of bivalve species are also highly related to their adaptive abilities to withstand environmental variations. Species living on the substrate (mussels and oysters) in intertidal habitat encounter considerable daily temperature, food availability and salinity fluctuations, while quahog and soft-shell clams are in more stable environmental conditions in the buried habitat at intertidal or subtidal levels. Thus, mussels and oysters have better plasticity to respond to temperature changes which could be a factor acting in their higher scope for growth measured.

\subsection{Differences between farmed and wild}

Minor physiological differences have been observed between cultivated and wild bivalves, specifically for oysters and mussels. This outcome suggests that aquaculture practices have no important impacts on the phenotypic physiological characteristics of these bivalve species. Four times higher oxygen consumption in wild mussels were observed comparatively to cultivate ones, although this difference disappeared in autumn. To our knowledge, no study has previously reported such difference in oxygen uptake between wild and cultivated bivalves. The differences in reproductive cycle between suspended cultivated and intertidal mussels could be an explanation (Bayne, 2000; Cranford and Hill, 1999; Tedengren et al., 1990), at least with respect to the autumnal results. We assume that all mussels were in post-spawning states in autumn, explaining the similar oxygen consumption observed at this time of year. Secondly, a $2.3 \%$ difference in assimilation efficiency was observed between cultivated and wild mussel in autumn. However, since the assimilation efficiency of pure microalgae culture of Tisochrysis lutea was over $90 \%$, the biological impact of this difference was weak and ultimately not reflected in SFG. This result agrees with literature, as absorption efficiency values of cultured (Babarro et al., 2003) and wild mussels (Navarro et al., 2003) fluctuated mainly according to quality of seston. Isochrysis sp. culture is more digestible than microalgae in natural seston (Velasco and Navarro, 2005) and no relationship between absorption efficiency and body size was observed for different mollusk species (Velasco et al., 2019).

Few articles compared physiological rates between wild and cultivated bivalves. Comeau (2013) compared the CR of oysters cultivated on the bottom with those cultivated in suspension. It was reported that bottom oysters had a relatively high CR. It is therefore not surprising that $\mathrm{CR}$ variability was important in wild individual oysters, particularly in summer. We suggest that different contributions of somatic, reserve or reproductive tissues in total tissue weight induced by different life history have probably affected the standardized CR measured. Different life history of wild oysters could induce differential timing in the release of gametes explaining the important CR variability observed in oysters. Overall, results suggest that considering the biomass of oysters and mussels, no matter their origins (wild or cultivated), is crucial for 
improving the carrying capacity models of Malpeque Bay. However, interpretation of the data must be taken with caution as the $\mathrm{CR}$ and oxygen consumption represent the maximal values obtained during the 1-hour measurement and not the daily average.

\section{Conclusion}

Prince Edward Island blue mussels (M. edulis) consistently exhibited high CR and SFG values over the summer-autumn period. American oysters (C. virginica) and softshell clams $(M$. arenaria) similarly displayed elevated CR and SFG values, although only during summer as these physiological parameters decreased sharply in autumn. These observations suggest that in cold water, oysters and softshell clams have less impact (filtration) than mussels on finite seston resources available in the system. For quahogs ( $M$. mercenaria), the measured physiological parameters were low for both seasonal temperatures. When combining this information with the species limited distribution in the bay, it is concluded that quahogs have little impact on available food resources. For mussels and oysters, the physiological measurements were generally similar between wild and cultivated individuals, suggesting that origin (wild and cultivated) is not an important element in carrying capacity models. It is possible that, in summer, oysters exert the strongest food pressure on the phytoplankton community given their high $\mathrm{CR}$ and extended distribution in the system, particularly the wild individuals. In their studies, Filgueira et al. (2015b) and DFO (2015) estimated stocks of farmed mussels and oysters, but they recognized a lack of knowledge for wild populations. It is likely that wild mussels account for a negligible portion of the bivalve biomass in the bay as there are few areas offering hard substrates for proper byssal attachment. The seabed located under mussel longlines may be covered by mussels originating from suspended sleeves, i.e. cultured mussels that are subject to fall-off under turbulent conditions and/or through adjustment of density (Lachance et al., 2011). However, these mussels are generally subject to high predation levels (crabs, sea stars, lobsters, moon snails), as suspension culture enhances epibenthic macrofauna (D'Amours et al., 2008). Thus, wild mussels probably have a limited impact on the phytoplankton biomass. Finally, in order to obtain robust estimates of carrying capacity, the biomass of each bivalve group in the system needs to be adequately quantified. For the Malpeque system this conclusion applies particularly to mussels, oysters and soft-shell clams as their grazing capacity was particularly notable compared to other bivalves.

\section{References}

Abbot RT. 1974. American Seashells; the marine mollusca of the atlantic and pacific coats of North America. 2. Ed. New York, USA: Van Nostrand Reinold.

Ansell AD. 1968. The rate of growth of the hard clam Mercenaria mercenaria (L.) throughout the geographical range. J Cons Int Expl Mer 31: 364-409.

Arnold WS, Marelli DC, Bert TM, Jones DS, Quitmyer IR. 1991. Habitat-specific growth of hard clam Mercenaria mercenaria (L.) from the Indian River, Florida. J Exp Mar Biol Ecol 147: 245-265.
Babarro JMF, Fernandez-Reiriz MJ, Labarta U. 2003. Insitu absorption efficiency processes for the cultured mussel Mytilus galloprovincialis in Ria de Arousa (north-west Spain). J Mar Biol Ass UK 83: 1059-1064.

Bayne BL. 2000. Relations between variable rates of growth, metabolic costs and growth efficiencies in individual Sydney rock oysters (Saccostrea commercialis). J Exp Mar Biol Ecol 251: 185-203.

Bayne BL. 1999. Physiological components of growth differences between individual oysters (Crassostrea gigas) and a comparison with Saccostrea commercialis. Physiol Biochem Zool 72: 705-13.

Bayne BL. 1976. Physiology 1. Marine mussels: Their ecology and physiology. In: Marine Mussels: Their Ecology and Physiology. New York, NY, pp. 121-207.

Bricelj M, Macquarrie P, Scha A. 2001. Differential effects of Aureococcus anophagefferens isolates ("brown tide") in unialgal and mixed suspensions on bivalve feeding. Mar Biol 139: 605-615.

Byron CJ, Costa-Pierce B. 2013. Carrying capacity tools for use in the implementation of an ecosystems approach to aquaculture. In L.G. Ross, T.C. Telfer, L. Falconer, D. Soto, J. Aguilar-Manjarrez (Eds.), Site selection and carrying capacities for inland and coastal aquaculture, FAO/Institute of Aquaculture, University of Stirling, Expert Workshop, 6-8 December 2010. Stirling, the United Kingdom of Great Britain and Northern Ireland. FAO Fisheries and Aquaculture Proceedings No. 21. Rome, FAO, pp. 87-101. $282 \mathrm{pp}$.

Carriker MR, Gaffney PM. 1996. A catalogue of selected species of living oysters (Ostreacea) of the world. In: V.S. Kennedy, R.I.E. Newell, A.F. Eble (Eds.),The Eastern Oyster Crassostrea virginica, in: MD (Ed.), The Eastern Oyster Crassostrea Virginica. pp. $1-18$.

Comeau LA. 2013. Suspended versus bottom oyster culture in eastern Canada: Comparing stocking densities and clearance rates. Aquaculture 410-411: 57-65.

Comeau LA, Drapeau A, Landry T, Davidson J. 2008a. Development of longline mussel farming and the in fluence of sleeve spacing in Prince Edward Island, Canada. Aquaculture 281: 56-62.

Comeau LA, Guyondet T, Sonier R. 2015. The impact of invasive tunicates on the demand for phytoplankton in longline mussel farms. Aquaculture 441: 95-105.

Comeau LA, Mayrand E, Mallet A. 2012. Winter quiescence and spring awakening of the Eastern oyster Crassostrea virginica at its northernmost distribution limit. Mar Biol 159: 2269-2279.

Comeau LA, Pernet F, Tremblay R, Bates SS, Leblanc A. 2008 b. Comparison of eastern oyster (Crassostrea virginica) and blue mussel (Mytilus edulis) filtration rates at low temperatures. Can Tech Rep Fish Aquat Sci 2810: 1-17.

Conover RJ. 1966. Assimilation of organic matter by zooplankton. Limnol Ocean 11: 338-345.

Cranford PJ, Dowd M, Grant J, Hargrave B, McGladdery SE. 2003. A scientific review of the potential environmental effects of aquaculture in aquatic ecosystems. Can Tech Rep Fish Aquac Sci 2450: 131.

Cranford PJ, Hill PS. 1999. Seasonal variation in food utilization by the suspension-feeding bivalve molluscs Mytilus edulis and Placopecten magellanicus. Mar Ecol Prog Ser 190: 223-239.

Cranford PJ, Li W, Strand Ø, Strohmeier T. 2008. Phytoplankton depletion by mussel aquaculture: high resolution mapping, ecosystem modelling and potential indicators of ecological carrying capacity. Ices $C$ 2008/H:12, 1-5. 
Cusson M, Tremblay R, Daigle G, Roussy M. 2005. Modeling the depuration potential of blue mussels (Mytilus spp.) in response to thermal shock. Aquaculture 250: 183-193.

D'Amours OD, Archambault P, Mckindsey CW, Johnson LE. 2008. Local enhancement of epibenthic macrofauna by aquaculture activities. Mar Ecol Prog Ser 371: 73-84.

Denis L, Alliot E, Grezbyk D. 1999. Clearance rate responses of Mediterranean mussels, Mytilus galloprovincialis, to variations in the flow, water temperature, food quality and quantity. Aquat Living Resour 12: 179-188.

DFO 2015. Carrying capacity for shellfish aquaculture with reference to mussel aquaculture in Malpeque Bay, Prince Edward Isaland. DFO Can Sci Advis Sec Sci Advis Rep 2015/003.

Delaporte M, Synard M, Pariseau J, McKenna P, Tremblay R, Davidson J, Berthe FCJ. 2008. Assessment of haemic neoplasia in different soft shell clam Mya arenaria populations from eastern Canada by flow cytometry. J Invert Path 98: 190-197.

Dillon RTJ, Manzi JJ. 1992. Population genetics of the hard clam, Mercenaria mercenaria, at the northern limit of its range. Can J Fish Aquat Sci 42: 2574-2578.

Drapeau A, Comeau LA, Landry T, Stryhn H, Davidson J. 2006. Association between longline design and mussel productivity in Prince Edward Island, Canada. Aquaculture 261: 879-889.

Filgueira R, Comeau LA, Guyondet T. 2015a. Modelling carrying capacity of bivalve aquaculture: a review of definitions and methods. DFO Can Sci Advis Sec Res Doc 2015/002. v + 31 p.

Filgueira R, Guyondet T, Bacher C, Comeau LA. 2015b. Carrying capacity for mussel aquaculture in Malpeque Bay, Prince Edward Island. DFO Can Sci Advis Sec Res Doc 2015/, v + 36 p.

Filgueira R, Comeau LA, Landry T, Grant J, Guyondet T, Malle A. 2013. Bivalve condition index as an indicator of aquaculture intensity: a meta-analysis. Ecol Indic 25: 215-229.

Gibbs MT. 2007. Sustainability performance indicators for suspended bivalve aquaculture activities. Ecol Indic 7: 94-107.

Gilek M, Tedengren M, Kautsky N. 1992. Physiological performance and general histology of the blue mussel Mytilus edulis from the Baltic and North Seas. Neth J Sea Res 30: 11-21.

Gosling E. 1992. Systematics and geographic distribution of Mytilus. In The mussel Mytilus: Ecology, physiology, genetics and culture. Developments in aquaculture and fisheries science No25, Elsevier, Amsterdam, pp. 1-20.

Grant J, Curran KJ, Guyondet TL, Tita G, Bacher C, Koutitonsky V, Dowd M. 2007. A box model of carrying capacity for suspended mussel aquaculture in Lagune de la Grande-Entrée, Iles-de-laMadeleine, Québec. Ecol Modell 200: 193-206.

Guyondet T, Comeau LA, Bacher C, Grant J, Rosland R, Sonier R, Filgueira R. 2015a. Climate change influences carrying capacity in a coastal embayment dedicated to shellfish aquaculture. Estuar Coasts 38: 1593-1618.

Guyondet T, Comeau LA, Bacher C, Grant J, Rosland R, Sonier R, Filgueira R. 2015b. Climate change influences productivity of cultivated mussels. Estuar Coasts 38: 1593-1618.

Guyondet T, Roy S, Koutitonsky VG, Grant J, Tita G. 2010. Integrating multiple spatial scales in the carrying capacity assessment of a coastal ecosystem for bivalve aquaculture. $J$ Sea Res 64: 341-359.

Harke MJ, Gobler CJ, Shumway SE. 2011. Suspension feeding by the Atlantic slipper limpet (Crepidula fornicata) and the northern quahog (Mercenaria mercenaria) in the presence of cultured and wild populations of the harmful brown tide alga, Aureococcus anophagefferens. Harmful Algae 10: 503-511.

Harte ME. 2001. Systematics and Taxonomy, In: Biology of the Hard Clam. J.N. Kraeuter, M. Castagna (Eds.), Developments in aquaculture and fisheries science No31. Amsterdam: Elsevier, pp. 3-52.

Hilbish T. 2001. Genetics of hard clams, Mercenaria mercenaria. In: J. N. Kraeuter, M. Castagna (Eds.), Biology of the Hard Clam. Developments in Aquaculture and Fisheries Science, No. 31. Amsterdam: Elsevier, pp. 261-280.

Jones DS, Athur MA, Allard DJ. 1989. Sclerochronological reccords of temperature and growth from shells of Mercenaria mercenaria from Narraganestt Bay. Mar Biol 102: 225-234.

Jones DS, Quitmyer IR, Arnold WS, Marelli DC. 1990. Annual shell banding, age, and growth rate of hard clams (Mercenaria spp.) from Florida. $J$ Shellfish Res 9: 215-225.

Jones J, Allam B, Espinosa EP. 2020. Particle selection in suspension-feeding bivalves: Does one model fit all? Biol Bull 238.

Jørgensen C, Larsen P, Riisgaård H. 1990. Effects of temperature on the mussel pump. Mar Ecol Prog Ser 64: 89-97.

Lachance A, Hennebicq R, Myrand B, Sévigny J-M, Kraffe E, Marty Y, Marcotte I, Tremblay R. 2011. Biochemical and genetic characteristics of suspension-cultured mussels (Mytilus edulis) in relation to byssal thread production and losses by fall-off. Aquat Living Resour 293: 283-293.

Landry T, Sephton TW, Jones DA. 1993. Growth and mortality of northern quahog, Mercenaria mercenaria (Linneaeus, 1758) in Prince Edward Island. J Shellfish Res 12: 321-327.

Le DV, Alfaro AC, Ibarrola I, Ragg NLC, Hilton Z, King N. 2017. Allometric scaling of physiological rates in the New Zealand geoduck clam, Panopea zelandica. Aquaculture 473: 105-109.

Loosanoff VL. 1958. Some aspects of behavior of oysters at different temperatures. Biol Bull 114: 57-70.

Mallet AL, Myrand B. 1995. The culture of the blue mussel in Atlantic Canada., In: A.D. Boghen (Ed.), Cold-Water Aquaculture in Atlantic Canada, 2nd edn. Moncton, Canada.

McKindsey CW, Thetmeyer H, Landry T, Silvert W. 2006. Review of recent carrying capacity models for bivalve culture and recommendations for research and management. Aquaculture 261: 451-462.

Myrand B, Tremblay R, Sévigny J. 2009. Impact of suspension culture using mesh sleeves on genetic characteristics of Mytilus edulis L. in Canada. Aquaculture 291: 147-153.

Navarro JM, Labarta U, Fernandez-Reiri MJ, Velasco A. 2003. Feeding behavior and differential absorption of biochemical components by the infaunal bivalve Mulinia edulis and the epibenthic Mytilus chilensis in response to changes in food regimes. J Exp Mar Biol Ecol 287: 13-35.

Newell CR, Wildish DJ, MacDonald BA. 2001. The effects of velocity and seston concentration on the exhalant siphon area, valve gape and filtration rate of the mussel Mytilus edulis. J Exp Mar Biol Ecol 262: 91-111.

Perez-Camacho A, Gonzalez R, Fuentes J. 1991. Mussel culture in Galicia (N.W. Spain). Aquaculture 94: 263-278.

Pernet F, Tremblay R, Comeau L, Guderley K. 2007. Temperature adaptation in two bivalve species from different thermal habitats: energetics and remodelling of membrane lipids. J Exp Biol 210: 2999-3014.

Pernet F, Tremblay R, Redjah I, Sevigny J-M, Gionet C. 2008. Physiological and biochemical traits correlate with differences in growth rate and temperature adaptation among groups of the eastern oyster Crassostrea virginica. J Exp Biol 211: 969-977.

Riisgård HU. 1998. No foundation of a "3/4 power scaling law" for respiration in biology. Ecol Lett 1: 71-73. 
Riisgård HU, Seerup DF. 2003. Filtration rates in the soft clam Mya arenaria: effects of temperature and body size. Sarsia 88: 416-428.

Rosa M, Ward J, Shumway S. 2018. Selective capture and ingestion of particles by suspension-feeding bivalve molluscs: a review. $J$ Shellfish Res 37: 727-746.

Sonier R, Filgueira R, Daoud D, Comeau LA. 2018. Feeding pressure of Mytilus edulis and Styela clava on phytoplankton and zooplankton, including lobster larvae (stages I and IV). Can Tech Rep Fish Aquat Sci 3263: vi + 19 p.

Sonier R, Filgueira R, Guyondet T, Tremblay R, Olivier F, Meziane T, Starr M, Leblanc AR, Comeau LA. 2016. Picophytoplankton contribution to Mytilus edulis growth in an intensive culture environment. Mar Biol 163: 73-88.

Tedengren M, Andre C, Johannesson K, Kautsky N. 1990. Genotypic and phenotypic differences between Baltic and North Sea populations of Mytilus edulis evaluated through reciprocal transplantations. II. Genetic variation Mar Ecol Prog Ser 59: 211-219.

Tremblay R, Landry T. 2016. The implication of metabolic performance of Mytilus edulis, Mytilus trossulus, and hybrids for mussel aquaculture in Eastern Canadian waters. J Mar Biol Aquacult 2: 1-7.

Tremblay R, Belvin S, Thomas B. 2012. Suivi pathologique des bivalves aux sites d'élevage commerciaux et expérimentaux. SODIM Report, 37p.

Tremblay R, Landry T, Leblanc N, Pernet F, Barkhouse C, Sévigny J. 2011. Physiological and biochemical indicators of mussel seed quality in relation to temperatures. Aquat Living Resour 24: 273-282.

Tremblay R, Myrand B, Sevigny JM, Blier P, Guderley H. 1998. Bioenergetic and genetic parameters in relation to susceptibility of blue mussels, Mytilus edulis (L.) to summer mortality. J Exp Mar Biol Ecol 221: 27-58.

Trottet A, Roy S, Tamigneaux E, Lovejoy C, Tremblay R. 2008. Impact of suspended mussels (Mytilus edulis L.) on plankton communities in a Magdalen Islands lagoon (Québec, Canada): a mesocosm approach. J Exp Mar Biol Ecol 365: 103-115.

Velasco LA, Carreño-Aguirre A, Toro B. 2019. Effect of body size on the energetic physiology of the west Indian top shell cittarium pica (Linnaeus, 1758). Lat Am J Aquat Res 47: 251-259.

Velasco LA, Navarro JM. 2005. Feeding physiology of two bivalves under laboratory and field conditions in response to variable food concentrations. Mar Ecol Prog Ser 291: 115-124.

Waite L, Grant J, Davidson J. 2005. Bay-scale spatial growth variation of mussels Mytilus edulis in suspended culture, Prince Edward Island, Canada. Mar Ecol Prog Ser 297: 157-167.

Walne P. 1972. The influence of current speed, body size and water temperature on the filtration rate of five species of bivalves. $J$ Mar Biol Assoc UK 52: 345-374.

Widdows J. 1985. Physiological procedures. In: B.L. Bayne, D.R. Livingstone, D.M. Lowe, M.N. Moore, A.R.D. Stebbing, J. Widdows (Eds.), The effects of stress and pollution on marine animals. New York: Praeger, pp. 161-178.

Widdows J. 1978. Combined effects of body size, food concentration and season on the physiology of Mytilus edulis. J Mar Biol Assoc UK 58: 109-124.

Widdows J, Johnson D. 1988. Physiological energetics of Mytilus edulis: Scope for Growth. Mar Ecol Prog Ser 46: 113-121.

Winter J. 1978. A review of the knowledge of suspension feeding lamellibranchiate bivalves, with special reference to artificial aquaculture systems. Aquaculture 13: 1-33.

Cite this article as: Montagnac V, Guyondet T, Comeau L, Tremblay R. 2020. Physiological differences between wild and cultured bivalves in Prince Edward Island, Canada. Aquat. Living Resour. 33: 8 